\title{
PERANCANGAN ARSITEKTUR BISNIS PENGEMBANGAN PEMBELAJARAN PERGURUAN TINGGI DI INDONESIA BERBASIS ORGANIZATIONAL LEARNING DENGAN PENDEKATAN TOGAF ADM
}

\author{
Heriyono Lalu \\ Program Studi Teknik Industri, Fakultas Rekayasa Industri, Telkom University \\ heriyonolalu@telkomuniversity.ac.id
}

\begin{abstract}
Abstrak-Keberhasilan dalam pengembangan dan penerapan organizational learning serta pengelolaan pengetahuan merupakan faktor kunci bagi kesuksesan dan produktivitas organisasi. Perguruan Tinggi merupakan sebuah organisasi yang seharusnya adalah sebuah learning organization, termasuk perguruan tinggi di Indonesia. Di Indonesia, tata kelola perguruan tinggi telah diatur secara ketat dalam banyak peraturan perundangan dan standar-standar akreditasi. Aturan dan standar tersebut juga termasuk di dalamnya tentang pengembangan pembelajaran. Penelitian ini ingin menawarkan sebuah model arsitektur bisnis pengembangan pembelajaran yang sejalan dengan aturan dan akreditasi perguruan tinggi di Indonesia, dan juga dirancang sebagai model organizational learning di perguruan tinggi Indonesia. Arsitektur bisnis pengembangan pembelajaran berbasis organizational leraning dimaksud dirancang dengan mengikuti kelengkapan komponen arsitektur dan fase pengembangan arsitektur dalam TOGAF ADM yaitu business motivation pengembagan pembelajaran, organizational units pegembangan pembelajaran, business functions and services pengembangan pembelajran, business processes pengembangan pembelajaran, dan business roles and actors pengembangan pembelajaran.
\end{abstract}

Kata kunci: Arsitektur Bisnis, TOGAF ADM, Organizational Learning, Perguruan Tinggi Indonesia, Pengembangan Pembelajaran.

\section{PENDAHULUAN}

Perguruan Tinggi (PT) di Indonesia merupakan sebuah institusi pendidikan yang diatur secara ketat oleh pemerintah mulai dari level undang - undang, peraturan pemerintah, peraturan mentri, petunjuk Direktorat Jendral Pendidikan Tinggi, sampai pada standar - standar yang ditetapkan dalam standar akreditasi oleh Badan Akreditasi Nasional Perguruan Tinggi (BAN PT). Standar akreditasi berupa standar akreditasi institusi penyelenggara pendidikan tinggi dan akreditasi program pendidikan yang diselenggarakan. Di sisi lain, perguruan tinggi dihadapkan pada perubahan lingkungan internal dan perubahan lingkungan eksternal. Perubahan lingkungan internal berhubungan dengan perkembangan sivitas akademika dan kebijakan-kebijakan yang diambil oleh perguruan tinggi. Perkembangan eksternal berhubungan dengan perubahan karakter peserta didik, perubahan ilmu pengetahuan dan teknologi, sampai pada tantangan relasi dengan perguruan tinggi yang lain. Regulasi yang ketat, dan tantangan internal maupun eksternal yang cepat memberi tantangan perguruan tinggi untuk terus tumbuh dan sustainable dengan terus mengelola kunci sukses dan produktivitas dengan baik.

Kesuksesan dan produktivitas sebuah organisasi termasuk perguruan tinggi, salah satunya ditentukan oleh keberhasilannya dalam membangun dan menerapkan organizational learning (Information Resources Management Association, 2012). Proses Organizational learning merupakan sebuah proses adaptasi pada semua tingkatan organisasi. Organizational learning dapat terjadi pada tingkat individu, kelompok, unit kerja, sampai pada satu kesatuan organisasi itu sendiri(Lalu, 2014). Vits \& Gelders (2002) dalam(Lalu, 2014) menjelaskan bahwa pada tingkat organisasi, learning dapat terjadi melalui pelatihan - pelatihan atau perubahan design (second order learning). Learning juga dapat terjadi melalui proses belajar yang dilakukan oleh pelaksana atau operator (first order learning).

Perguruan Tinggi merupakan sebuah organisasi yang seharusnya berperan sebagai learning organization. Proses learning pada tingkat organisasi pada perguruan tinggi dapat dilakukan dengan penerapan quality management pada pengembangan akademik, dan pengembangan profesionalisme dosen (Alegre \& Villar, 2012). Pengembangan profesionalisme dosen dan pengembangan akademik perguruan tinggi di Indonesia koheren dengan membangun lingkungan pembelajaran. Lingkungan pembelajaran merupakan ekosistem tempat interaksi antara pembelajar, dosen, dan sumber belajar (Pemerintah Republik Indonesia, 2014). Standar lima akreditasi institusi perguruan tinggi Indonesia menetapkan adanya pengembangan pembelajaran yang menjalankan fungsi mengembangkan sistem dan mutu pembelajaran dalam pengelolaan pembelajaran di perguruan tinggi (Badan Akreditasi Nasional Perguruan Tinggi (BAN PT), 2011).

Pengembangan pembelajaran berhubungan erat dengan pengembangan dosen melalui pelatihan - pelatihan profesional, sistem mutu pembelajaran, dan perancangan (design) pembelajaran. Proses adaptasi terhadap perubahan dalam konteks pengembangan pembelajaran, sesuai definisi Vits \& Gelders (2002) dalam (Lalu, 2014), merupakan Second Order Learning (SOL) pada perguruan tinggi. Dosen sebagai professional pembelajaran juga dapat melakukan adaptasi dari pengalaman operasioanal pembelajaran. 
Learning dari proses ini merupakan First Order Learning (FOL). Berdasarkan ketentuan perundangan, standar akreditasi, dan teori di atas, maka perlu dirancang sebuah arsiterktur organizational learning bagi perguruan tinggi di Indonesia yang dapat memenuhi peraturan perundangan dan standar akreditasi, di samping memfasilitasi proses First Order Learning (FOL) dan Second Order Learning (SOL).

Arsitektur organisasi dapat dimodelkan ke dalam arsitektur bisnis, arsitektur aplikasi dan data, serta arsitektur infrastruktur. Dalam penelitian ini, pengembangan arsitektur organizational learning berbasis pengembangan pembelajaran yang dimodelkan adalah arsitektur bisnis dengan menggunakan TOGAF ADM. Dalam TOGAF ADM, kelengkapan arsiterktur bisnis meliputi business motivation, organizational units, business functions and services, business processes, dan business roles and actors (Desfray \& Raymond, 2014). Dengan pendekatan ini, diharapkan penelitian ini menghasilkan arsitektur organizational learning pada perguruan tinggi berbasis pengembangan pembelajaran yang memenuhi ketentuan dan standar akreditasi di Indonesia.

\section{METODE PENELITIAN}

Tahapan perancangan arsitektur bisnis pengembangan pembelajaran berbasis organizational learning mengikuti tahapan TOGAF Architecture Development Model (ADM) Cycle. ADM Cycle terdiri atas delapan fase, yaitu fase A: Vision; fase B: Business architecture; fase C: Information system architecture; fase D: Technology architecture; fase E: Opportunities and solutions; fase F: Migration planning; fase G: Implementation governance; fase $\mathrm{H}$ : Architecture change management (Desfray \& Raymond, 2014). Sesuai kebutuhan penelitian, maka tahapan perancangan ADM Cycle yang digunakan adalah sampai pada fase B yaitu pengembangan arsitektur bisnis seperti Gambar 1 di bawah ini.

1. Definisi Lingkup dan Pihak Terkait

Tahap ini merupakan pengembangan visi dari arsitektur bisnis pengembangan pembelajaran perguruan tinggi berbasis organizational learning. Untuk keperluan ini dibutuhkan identifikasi pihak yang terlibat seperti dosen, manajemen Perguruan Tinggi, Kelompok Keahlian (faculty), pelaksana program (prodi), dan ketentuan yang terkait (Pemerintah, BAN PT).

2. Deskripsi Sasaran Arsitektur

Pada tahap ini, berdasarkan lingkup dan kepentingan dari berbagai pihak terkait, dikembangkan sasaran (objectives) dari arsitektur bisnis yang akan dibuat. Sasaran ini berhubungan dengan kepentingan organisasi dan organizational learning yang diharapkan.

3. Analisis - dilakukan dalam rangka evaluasi kebutuhan fungsional, kebuhtuhan proses bisnis, kebutuhan peran dan tanggungjawab, serta kebutuhan pada tingkat first dan second order learning.

4. Definisi Arsitektur Bisnis

Berdasarkan hasil analisis pada langkah ke-3, dibuat gambaran dan deskripsi arsitektur bisnis pengembangan pembelajaran berbasis organizational learning dengan mempertimbangkan peraturan dan standar akreditasi yang berlaku di Indonesia.
Arsitektur bisnis dimaksud meliputi:

a. business motivation pengembangan pembelajaran,

b. organizational units pengembangan pembelajaran,

c. business functions and services pengembangan pembelajaran,

d. business processes pengembangan pembelajaran, dan

e. business roles and actors pengembangan pembelajaran.

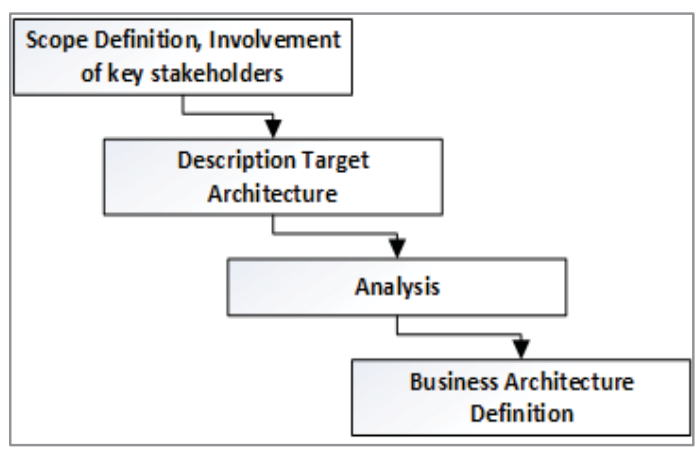

Gambar 1 Tahapan Perancangan Arsitektur Bisnis ( (Desfray \& Raymond, 2014))

\section{HASIL DAN PEMBAHASAN}

Sesuai tahapan perancangan arsitektur bisnis dengan TOGAF ADM, diperoleh lima hasil rancangan, yaitu business motivation, organizational units, business functions and services, business process, dan business roles and actors. Kelima komponen arsitektur tersebut menggambarkan arsitektur bisnis pengembangan pembelajaran perguruan tinggi di Indonesia sebagai basis organizational learning terhadap proses perancangan (design) pembelajaran, pelaksanaan pembelajaran, dan pengembangan Dosen di perguruan tinggi.

\section{A. Business Motivation}

Business motivation merupakan sasaran (objective) yang ingin dicapai dengan memperhatikan lingkup dan kepentingan pihak yang terkait.

\section{Scope Definition}

Pembelajaran adalah proses interaksi peserta didik dengan pendidik dan sumber belajar pada suatu lingkungan belajar (Pemerintah Republik Indonesia, 2003). Tujuan proses pembelajaran adalah untuk mewujudkan suasana belajar dan proses pembelajaran agar peserta didik mendapatkan capaian pembelajaran yang ditentukan. Berdasarkan definisi ini, maka terdapat elemen - elemen pembelajaran yang harus dikembangkan oleh perguruan tinggi di Indonesia (Tabel I).

Lingkup pengembangan pembelajaran adalah pengembangan sistem pembelajaran, yaitu pengembangan kurikulum, pengembangan rencana pembelajaran, pengembangan mahasiswa, pengembangan dosen, dan pengembangan sarana dan teknologi pembelajaran. Setiap komponen sistem berkembang melalui proses learning. Framework yang diusulkan sebagai lingkup pengembangan sistem pembelajaran seperti Gambar 2. 
TABEL I

KOMPONEN SISTEM PEMBELAJARAN

\begin{tabular}{|c|c|}
\hline Elemen Sistem & Deskripsi Elemen Sistem Pembelajaran \\
\hline $\begin{array}{l}\text { Tujuan } \\
\text { Pembelajaran } \\
\text { (Kurikulum da } \\
\text { Rancangan } \\
\text { pengajaran) }\end{array}$ & $\begin{array}{l}\text { Capaian pembelajaran seperti tertuang } \\
\text { dalam kurikulum. Kurikulum terdiri dari } \\
\text { banyak kajian, dan setiap kajian memiliki } \\
\text { tujuan pembalajaran yang merupakan } \\
\text { turunan dari capaian pembelajaran satu } \\
\text { kurikulum (Kementrian Riset, Teknologi } \\
\text { dan Pendidikan Tinggi, 2015). }\end{array}$ \\
\hline $\begin{array}{l}\text { Peserta Didik } \\
\text { (Mahasiswa) }\end{array}$ & $\begin{array}{l}\text { Subjek pembelajar yang harus aktif dan } \\
\text { mencapai tujuan pembelajaran }\end{array}$ \\
\hline Pendidik (Dosen) & $\begin{array}{l}\text { Fasilitator pembelajaran yang menyiapkan } \\
\text { konten, metode, petunjuk, dan pelaksanaan } \\
\text { pembelajaran }\end{array}$ \\
\hline $\begin{array}{l}\text { Sumber Belajar dan } \\
\text { Lingkungan Belajar }\end{array}$ & $\begin{array}{l}\text { Kelengkapan fasilitas, sarana dan } \\
\text { prasarana, dan teknologi yang mendukung } \\
\text { dan membentuk lingkungan belajar. }\end{array}$ \\
\hline
\end{tabular}

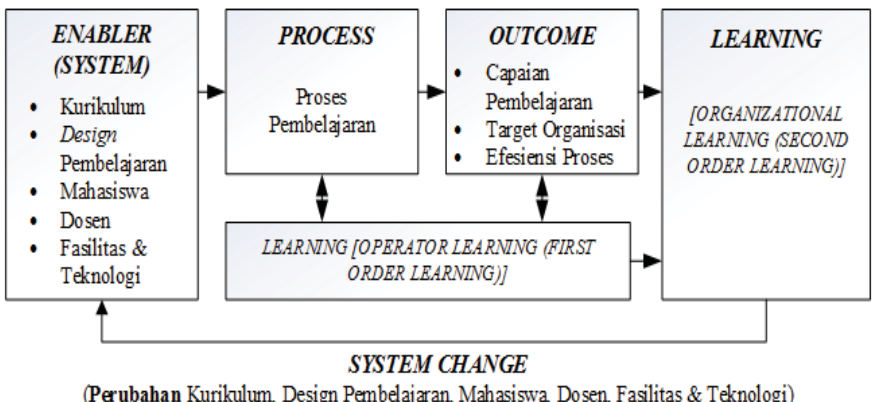

Gambar 2 Rancangan Lingkup Perilaku Sistem Pembelajaran Berbasis Organizational Learning

Learning merupakan proses adaptasi secara dinamis dalam rangka mencapai outcome yang diharapkan (Lalu, 2014). Pada sistem pembelajaran, terdapat tiga outcome yang diharapkan, yaitu sebagai berikut.

a. System Output: yaitu outcome yang merupakan tujuan dari sistem pembelajaran yaitu tercapainya capaian pembelajaran yang diharapkan.

b. System owner outcome: yaitu key performance indicator (KPI) yang ditetapkan oleh pemilik dari sistem pembelajaran (pimpinan perguruan tinggi).

c. System efficiency: yaitu ukuran seberapa hemat (waktu dan biaya) sistem pembelajaran dalam mencapai system outcome dan system owner outcome.

\section{Key Stakeholders Involve}

Pihak terkait dengan sistem pembelajaran memiliki berbagai kepentingan yang harus diperhatikan dalam mendefinisikan business motivation. Stakeholder yang terlibat disesuaikan dengan lingkup sistem pada Tabel I dan Gambar 2. Tabel II adalah hasil identifikasi stakeholder yang terlibat dan kepentingan terhadap sistem pembelajaran.

Berdasarkan pada lingkup sistem pembelajaran dan stakeholder terkait serta kepentingan dari setiap stakeholder, maka teridentifikasi tiga kata kunci motivasi sistem pembelajaran dan pengembanngannya yaitu: akreditasi, system outcome, dan sasaran strategis perguruan tinggi. Berdasarkar ketiga kata kunci ini, maka business motivation yang menjadi visi dari arsitektur bisnis yang dikembangkan adalah:

a. tercapaianya sasaran strategis pimpinan perguruan tinggi,

b. tercapainya capaian pembelajaran (IPK lulusan) dan lulusan tepat waktu sesuai yang ditargetkan, dan

c. terpenuhinya standar akreditasi program studi dan akreditasi institusi perguruan tinggi.

TABEL II

STAKEHOLDER SISTEM PEMBELAJARAN DAN KEPENTINGANNYA

\begin{tabular}{|l|l|}
\hline \multicolumn{1}{|c|}{ Stakeholder } & \multicolumn{1}{|c|}{ Kepentingan (Motivasi) } \\
\hline $\begin{array}{l}\text { Pimpinan } \\
\text { Perguruan }\end{array}$ & $\begin{array}{l}\text { Tercapainya sasaran strategis yang didefinisikan } \\
\text { dalam KPI system owner outcome. Disamping } \\
\text { itu, pimpinan perguruan tinggi juga } \\
\text { mengharapkan pengembangan sistem } \\
\text { pembelajaran yang memenuhi kriteria akreditasi. }\end{array}$ \\
\hline $\begin{array}{l}\text { Program } \\
\text { Studi }\end{array}$ & $\begin{array}{l}\text { a. Berjalannya proses pembelajaran sesuai } \\
\text { dengan jadwal dan rencana yang ditetapkan }\end{array}$ \\
& $\begin{array}{l}\text { IPK lulusan tercapai (system output) sebagai } \\
\text { indikator tercapainya capaian pembelajaran } \\
\text { (profil lulusan). }\end{array}$ \\
& $\begin{array}{l}\text { Lulusan tepat waktu tercapai (system } \\
\text { efficiency) } \\
\text { Ekpektasi ini sejalan dengan standar akreditasi } \\
\text { program studi yang berlaku di Indonesia. }\end{array}$ \\
\hline Dosen & $\begin{array}{l}\text { Dosen mengharapkan keaktifan mahasiswa } \\
\text { belajar dan mahasiswa dapat mencapai capaian } \\
\text { pembelajaran. }\end{array}$ \\
\hline Mahasiswa & $\begin{array}{l}\text { Mahasiswa mengharapkan dapat lulus dengan } \\
\text { IPK yang baik dan dalam waktu yang sesuai } \\
\text { dengan perencanaan. }\end{array}$ \\
\hline
\end{tabular}

\section{B. Organizational Units}

Capaian pembelajaran merupakan hasil dari rancangan dalam kurikulum. Kurikulum dijalankan dan dikelola oleh program studi (Pemerintah Republik Indonesia, 2014). Terkait dengan visi arsitektur (business motivation) butir a dan $b$, maka perguruan tinggi harus memiliki unit pengelola program yang disebut sebagai program studi.

Sejalan dengan visi arsitektur bahwa arsitektur bisnis harus memenuhi akreditasi program studi dan akreditasi institusi perguruan tinggi, maka sesuai standar 5 akreditasi insituti perguruan tinggi, setiap perguruan tinggi di Indonesia harus memiliki unit pengembangan pembelajaran (UPP) (Badan Akreditasi Nasional Perguruan Tinggi (BAN PT), 2011).

Dalam sistem pembelajaran, Dosen merupakan entitas yang sangat penting. Dosen merupakan knowledge worker dan menjadi aktor proses learning dalam sistem pembelajaran. Pentingnya peran dosen dan keilmuan yang dimiliki, menjadikan dosen harus dikelola dalam unit atau kelompok keilmuan yang disebut Fakultas atau kelompok keilmuan (KK).

Dari ketiga unit yang didefinisikan di atas, KK merupakan sumber knowledge worker (dosen) yang merupakan yang melakukan proses learning baik untuk aktivitas First Order Learning (FOL) maupun Second Order Learning (SOL). Program studi yang memiliki proses pembelajaran merupakan tempat dimana knowledge worker melakukan First Order Learning (belajar langsung saat aktivitas pembelajaran). UPP merupakan tempat knowledge worker melakukan 
aktivitas second order learning. Aktivitas learning baik FOL maupun SOL merupakan aktivitas pengembangan pembelajaran yang dilakukan oleh knowledge worker (dosen). Keterkaitan antara unit kerja dengan aktivitas learning dalam pengembangan pembelajaran digambarkan pada Gambar 3.

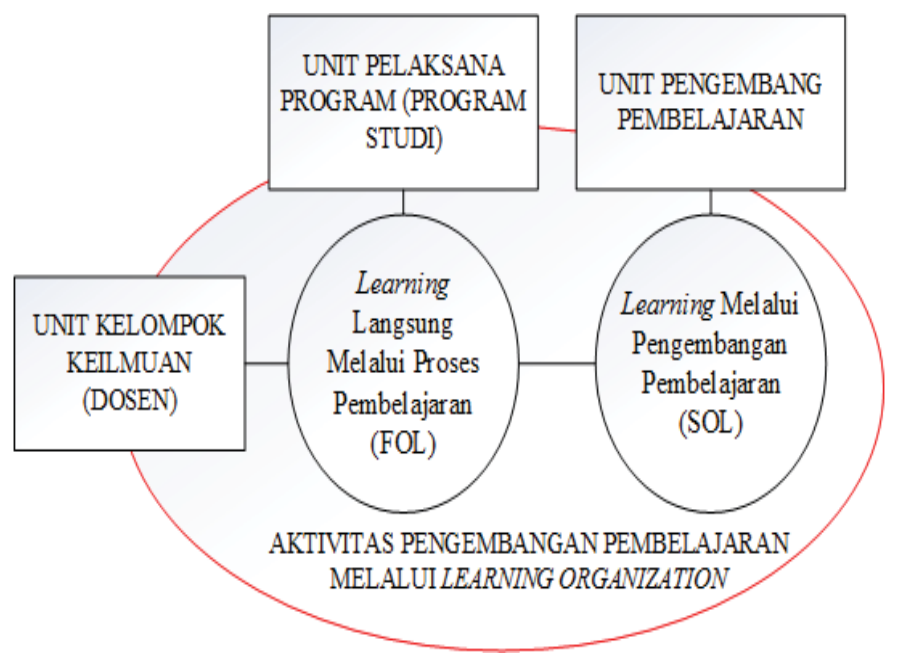

Gambar 3 Unit Organisasi dalam Arsitektur Bisnis Pengembangan Pembelajaran Berbasis Organization Learning

\section{Business Function and Services}

Fungsi bisnis dan layanan dalam arsitektur bisnis pengembangan pembelajaran sebagai proses learning organization didasarkan pada dua proses learning, yaitu First Order Learning (FOL) dan Second Order Learning (SOL). Kelengakapan fungsi dan layanan arsitektur bisnis pengembangan pembelajaran berbasis organizational learning diberikan pada Tabel 3.

Fungsi-fungsi dan layanan pada Tabel 3 di atas dijalankan oleh Unit Prodi dan Unit UPP. Dosen sebagai knowledge worker adalah pelaksana operasi dari setiap aktivitas. Pengaturan pembebanan dan pelaksana tugas dikelola oleh Kelompok Keilmuan (KK). Terdapat fungsi pengelolaan dosen yang terlibat dalam proses learning yang dilakukan oleh Unit KK. Fungsi dan layanan ini memperjelas gambaran unit kerja dan aktivitas learning pada Gambar 3. Fungsifungsi ini sejalan dengan tiga visi arsitektur pada business motivation.

TABEL III

FUNGSI BISNSI DALAM FOL DAN SOL BERBASIS PENGEMBANGAN PEMBELAJARAN PERGURUAN TINGGI

\begin{tabular}{|c|l|l|}
\hline $\begin{array}{c}\text { Learning } \\
\text { Type/Unit }\end{array}$ & \multicolumn{1}{|c|}{$\begin{array}{c}\text { Business (Learning) } \\
\text { Function }\end{array}$} & \multicolumn{1}{c|}{ Services } \\
\hline \multirow{5}{*}{ FOL } & $\begin{array}{l}\text { Pembaruan Rancangan } \\
\text { Pembelajaran MK } \\
\text { (retrieve knowledge) }\end{array}$ & $\begin{array}{l}\text { Layanan } \\
\text { Pengampuan Mata } \\
\text { Kuliah (MK) }\end{array}$ \\
\cline { 2 - 3 } $\begin{array}{c}\text { Penyelenggaraan } \\
\text { Unit }\end{array}$ & $\begin{array}{l}\text { Pembelajaran (create } \\
\text { Fungsional Layanan } \\
\text { perkuliahan } \\
\text { : Prodi }\end{array}$ & $\begin{array}{l}\text { b. Layanan praktek } \\
\text { c. Layanan praktikum }\end{array}$ \\
\cline { 2 - 4 } & $\begin{array}{l}\text { Evaluasi dan Penilaian } \\
\text { Hasil Belajar (create } \\
\text { new knowledge) }\end{array}$ & $\begin{array}{l}\text { a. Layanan Evaluasi } \\
\text { b. Layanan Ujian }\end{array}$ \\
\hline
\end{tabular}

\begin{tabular}{|c|c|c|}
\hline & $\begin{array}{l}\text { Pembuatan Portofolio } \\
\text { Pembelajaran (MK) } \\
\text { (store new knowledge) }\end{array}$ & $\begin{array}{l}\text { Layanan Portofolio } \\
\text { Mata Kuliah (MK) }\end{array}$ \\
\hline \multirow{2}{*}{$\begin{array}{l}\text { SOL / } \\
\text { Unit } \\
\text { Fungsional } \\
: \text { UPP \& } \\
\text { Prodi }\end{array}$} & $\begin{array}{l}\text { Pengembangan } \\
\text { Kurikulum (create \& } \\
\text { store knowledge) }\end{array}$ & $\begin{array}{l}\text { Layanan Evaluasi \& } \\
\text { Pengembangan } \\
\text { Kurikulum }\end{array}$ \\
\hline & $\begin{array}{lr}\text { Pembuatan rancangan } \\
\text { pembelajaran } \\
\text { (create \& } \\
\text { knowledge) }\end{array}$ & $\begin{array}{l}\text { Layanan standar dan } \\
\text { Pembuatan } \\
\text { rancangan } \\
\text { pembelajaran MK }\end{array}$ \\
\hline \multirow{3}{*}{$\begin{array}{l}\text { SOL / } \\
\text { Unit } \\
\text { Fungsional } \\
\text { : UPP }\end{array}$} & $\begin{array}{l}\text { Pelatihan Kompetensi } \\
\text { pengajaran } \\
\text { (create \& } \begin{array}{r}\text { Dosen } \\
\text { knowledge) }\end{array}\end{array}$ & $\begin{array}{l}\text { Layanan pelatihan } \\
\text { kompetensi } \\
\text { pengajaran dosen }\end{array}$ \\
\hline & $\begin{array}{l}\text { Kajian standar, metode } \\
\text { dan teknologi } \\
\text { pembelajaran (Top } \\
\text { Down) (create \& store } \\
\text { knowledge) }\end{array}$ & $\begin{array}{lr}\text { Layanan } & \text { kajian } \\
\text { pengembangan } & \text { dan } \\
\text { standar } & \text { mutu } \\
\text { pembelajaran } & \end{array}$ \\
\hline & $\begin{array}{lr}\text { Kajian standar, metode, } \\
\text { dan } & \text { teknologi } \\
\text { pembelajaran } & \text { berbasis } \\
\text { penelitian } & \text { tindakan } \\
\text { kelas } & \end{array}$ & $\begin{array}{l}\text { Layanan penelitian } \\
\text { tindakan kelas }\end{array}$ \\
\hline
\end{tabular}

\section{Business Process}

Berdasarkan fungsi dan layanan dalam pengembangan pembelajaran sebagai learning organization baik tipe FOL maupun tipe SOL, dilakukan perancangan proses bisnis dalam rangka mencapai sasaran arsitektur dalam business motivation. Proses bisnis yang dirancang haruslah menjadi proses belajar yang menghasilkan pengetahuan baru dalam rangka mencapai sasaran sistem, memenuhi standar akreditasi, dan efesiensi sistem pembelajaran. Proses bisnis digambarkan pada Gambar 4.

Proses bisnis pada Gambar 4 memperlihatkan proses penciptaan pengetahuan, penyimpanan pengetahuan, dan penggunaan kembali pengetahuan dalam mengembangkan sistem pembelajaran. Proses ini adalah proses learning pada sistem pembelajaran yang terjadi secara terorganisasi. Disamping memenuhi proses learning, proses pada Gambar 4, juga telah memenuhi standar 5 akreditasi institusi perguruan tinggi, standar akreditasi program studi, perbaikan efesiensi dan efektivitas sistem pemebelajaran secara berkelanjutan guna meningkatkan IPK lulusan dan lulusan tepat waktu. Dengan kata lain, proses bisnis selain memenuhi learning organization, juga dimaksudkan untuk mencapai tujuan dari arsitektur bisnis pengembangan pembelajaran (business motivation). 


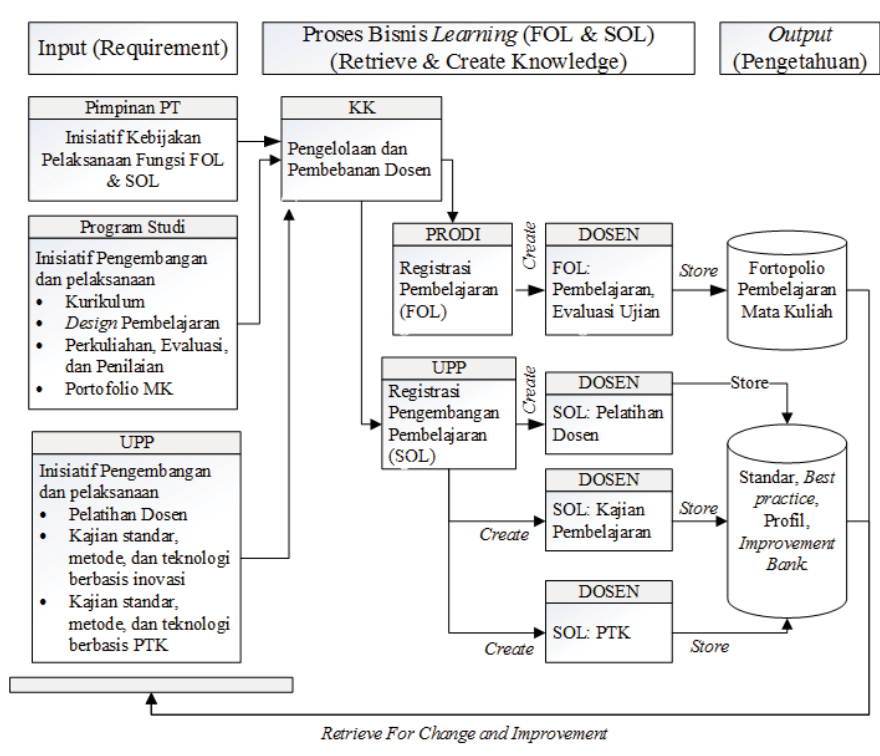

Gambar 4 Proses Bisnis Arsitektur Bisnis Pengembangan Pembelajaran Berbasis Organization Learning

\section{E. Business Roles and Actors}

Dalam perspektif object oriented design, pada proses bisnis arsitektur proses pengembangan pembelajaran berbasis learning organization pada Gambar 4, dapat diidentifikasi beberapa aktor penting dan peran yang dijalankan oleh setiap aktor. Aktor yang terlibat diantaranya adalah pimpinan perguruan tinggi, admin program studi, admin UPP, admin KK, dan dosen. Berdasarkan proses bisnis pada Gambar 4, setiap aktor memiliki peran penting guna keberhasilan proses mencapai tujuan dari arsiterktur bisnis. Aktor dan peran dalam arsitektur bisnis pengembangan pembelajaran berbasis organizational learning digambarkan dalam diagram use case di bawah ini.

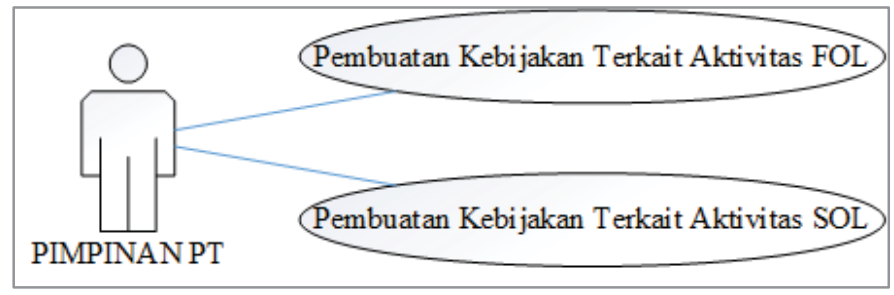

Gambar 5 Aktor pimpinan PT dan Peran yang Dijalankan

Aktor dan peran yang dijalankan oleh setiap aktor dalam lingkungan sistem pengembangan pembelajaran melayani terlaksananya proses dan juga organisasi dari proses. Karena proses yang diorganisasikan adalah proses pembelajaran (FOL dan SOL), maka perguruan tinggi yang mengimplementasikan model arsiterktur bisnis ini dapat menerapkan pengembangan pembelajaran sebagai model arsitektur pembelajaran organisasi.

Dosen memegang peran yang sangat penting dalam proses pemebelajaran organisasi perguruan tinggi berbasis pengembangan pembelajaran. Dosen merupakan aktor (knowledge worker) yang melaksanakan proses first order learning dan second order learning. Sumber-sumber pengetahuan berasal dari proses pembelajaran (SOL), proses pengembangan pembelajaran (FOL), dan sumber pengetahuan dari luar sistem melalui fungsi kajian standar, metode, dan teknologi pembelajran pada salah satu proses FOL.
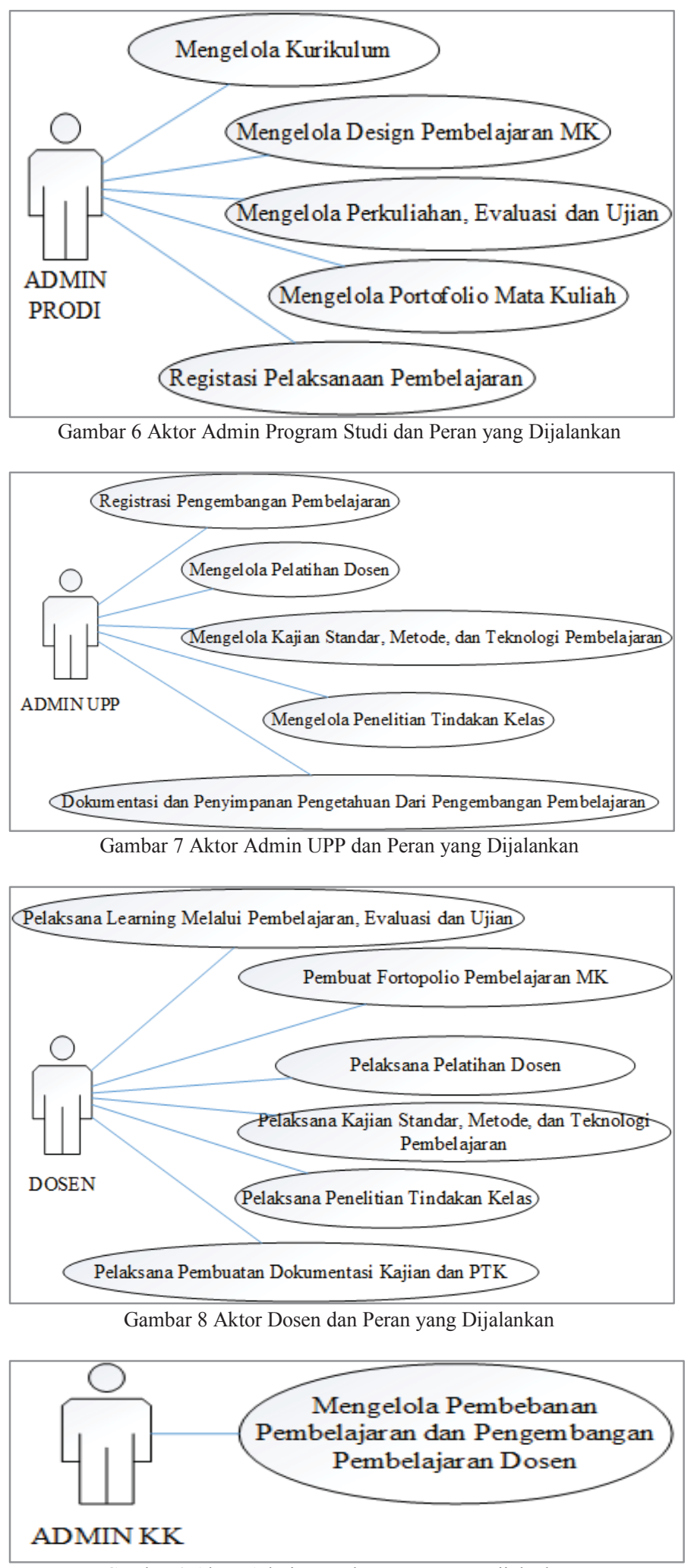

Gambar 9 Aktor Admin KK dan Peran yang Dijalankan

Peran organisasi pendukung lebih banyak dalam hal pengelolaan dan pengeorganisasian pelaksanaan proses learning yang akan dilakukan oleh Dosen. Pengetahuan yang dihasilkan oleh Dosen disimpan dan dapat digunakan oleh Dosen kembali sebagai upaya 
perbaikan berkelanjutan (adaptasi). Penyimpanan pengetahuan baru dapat dilakukan oleh dosen sendiri dan dapat juga dilakukan oleh organisasi yang menyelenggarakan proses.

\section{KESIIMPULAN}

Berdasarkan proses perancangan arsitektur bisnis pengembangan pembelajaran perguruan tinggi berbasis organizational learning, didapatkan beberapa sintesa yang dijadikan kesimpulan sebagai berikut:

1. Arsitektur bisnis pengembangan pembelajaran perguruan tinggi di Indonesia harus mempertikan undang - undang dan peraturan yang berlaku. Perhatian pada peraturan yang berlaku termasuk akreditasi perguruan tinggi akan memberikan arah bagi arsitektur bisnis pengembangan pembelajaran. Disamping itu, kepentingan internal perguruan tinggi harus diperhatikan. Berdasarkan pertimbangan eksternal dan internal ini, maka arah arsitektur bisnis pengembangan pembelajaran perguruan tinggi adalah tercapainya output sistem pembelajaran yaitu capaian pembelajaran dalam bentuk IPK lulusan, tercapainya efesiensi sistem pembelajaran yaitu lulusan tepat waktu, dan terpenuhinya standar akreditasi program studi maupun akreditasi institusi perguruan tinggi.

2. Lingkup sistem pembelajaran meliputi kurikulum dan rancangan pembelajaran, Mahasiswa, Dosen, dan Fasilitas dan Teknologi yang mendukung proses pembelajaran. Komponen sistem pembelajaran ini membentuk linkup enabler sistem, yang akan berproses dalam mencapai outcome dari sistem pembelajaran. Untuk membentuk lingkup sistem pembelajaran yang bersifat sistemik, perilaku sistem pembelajaran diperluas sampai perilaku learning baik first order learning (FOL) maupun second order learning (SOL).

3. Unit kerja yang terlibat dalam arsitektur bisnis pengembangan pembelajaran berbasis organizational learning melibatkan pimpinan perguruan tinggi, unit pengembangan pembelajaran (UPP), unit program studi, dan unit kelompok keilmuan (KK). Unit pimpinan perguruan tinggi memiliki fungsi kebijakan perguruan tinggi yang dapat mempengaruhi sasaran arsitektur. Unit UPP memiliki peran penting dalam berlangsungnya proses SOL yang meliputi pelatihan dosen, kajian pengembangan pembelajaran, dan pengembangan pembelajaran berbasis PTK. Unit program studi memiliki peran dalam pelaksanaan FOL yaitu proses pemebelajaran, evaluasi dan pengujian. Unit KK berperan dalam mengorganisasikan dan mengatur pembebanan dosen sebagai knowledge worker dari sistem pengembangan pembelajaran.

4. Proses pengembangan pembelajaran berbasis organizational learning dimulai dari inisiatif pengembangan dan pelaksanaan pembelajaran dari setiap unit kerja yang terlibat. Proses bisnis yang berlangsung pada dasarnya adalah proses pembuatan dan penggunaan pengetahuan. Pada akhir proses dibuat pengetahuan eksplisit yang disimpan baik dalam bentuk portofolio perkuliahan berbasis MK atau kumpulan hasil pengembangan pembelajaran. Pengetahuan yang dihasilkan ini dapat digunakan kembali dalam rangka perbaikan maupun perubahan elemen-elemen sistem pembelajaran yaitu kurikulum, rancangan pembelajaran, dosen, mahasiswa, fasilitas dan teknologi pembelajaran.
Pada penelitian ini, proses Architecture Development Model (ADM) hanya sampai pada pengembangan arsitektur bisnis. Penelitian lanjutan yang dapat dilakukan adalah dengan membuat arsitektur lanjutan yaitu arsitektur sistem informasi dan arsitektur teknologi. Arsitektur sistem informasi dan arsitektur teknologi menjadi penting karena proses learning dalam pengembangan pembelajaran adalah proses longitudinal yang membutuhkan ketersediaan data, informasi, dan dukungan teknologi. Disampin itu, arsitektur sistem informasi dan teknologi yang diteliti diarahkan dalam rangka mendukung proses pembelajaran (learning) yang harus terjadi baik itu first order learning (FOL) maupun second order learning (SOL).

\section{DAFTAR PUSTAKA}

[1] Information Resources Management Association, Organizational Learning and Knowledge: Concepts, Methodologies, Tools and Application, London: IGI Global, 2012.

[2] H. Lalu, Knowledge Sharing Antar Individu Dengan Learning Rate Bervariasi Pada Kasus Cross Selling Perbankan Nasional, Bandung: Institut Teknologi Bandung, 2014.

[3] O. M. Alegre and L. M. Villar, "Faculty Professional Learning: An Examination of Online Development and Assessment Environments," in Organizational Learning and Knowledge : Concepts, Methodologies, Tools and Aplication, London, IGI Global, 2012, p. 305.

[4] Pemerintah Republik Indonesia, Peraturan Pemerintah No. 14 Tahun 2014 Tentang Penyelenggaraan Pendidikan Tinggi dan Pengelolaan Perguruan Tinggi, Sekretariat Negara, Jakarta, 2014.

[5] Badan Akreditasi Nasional Perguruan Tinggi (BAN PT), Buku 6 Matrik Penilaian Borang dan Evaluasi Diri, Jakarta: Badan Akreditasi Nasional Perguruan Tinggi (BAN PT), 2011.

[6] P. Desfray and G. Raymond, Modeling Enterprise Architecture With TOGAF A Practical Guide Using UML and BPMN, Waltham USA: Elsevier Inc., 2014.

[7] Pemerintah Republik Indonesia, Undang - Undang No 20 Tahun 2003 Tentang Sistem Pendidikan Nasional, Jakarta: Sekretariat Negara Republik Indonesia, 2003.

[8] Kementrian Riset, Teknologi dan Pendidikan Tinggi, Peraturan Mentri No 44 Tahun 2015 Tentang Standar Nasional Pendidikan Tinggi, Jakarta: Sekretariat Negara Republik Indonesia, 2015. 